\title{
Compounds and multi-word expressions in Italian
}

\section{When two (or more) words come together}

It is often observed that compounds, being complex words formed by two (or more) words, are the morphological constructions closest to syntactic constructions, and that this is the reason why drawing a line between compounds and phrases is often difficult. Other complex lexical units challenge - possibly even more - the distinction between syntax, morphology and the lexicon: these are generally known as multi-word expressions (henceforth MWEs). MWEs are larger than morphological words and are nonetheless stored into our lexicon. The very existence of such MWEs poses a number of theoretical questions regarding (i) the organization of the lexicon, and (ii) the relationship between MWEs and compounds.

The first question has been addressed, among others, by Jackendoff (1995, 1997), who proposes to extend the lexicon to "multiword constructions" (1997: 153), including so-called “constructional idioms” (Jackendoff 1990: 221; cf. also Booij 2002a), since these phenomena are too pervasive to be regarded as a peripheral part of the grammar. This enlarged view of the lexicon is viable under such approaches as the Parallel Architecture (Jackendoff 2010), Construction Morphology (Booij 2010) and Construction Grammar in general (Hoffmann/Trousdale (eds.) 2013).

If we accept MWEs as part of our lexicon, we may want to address the second question, which is exactly what the present volume does. More specifically, we may ask:

a) Is there a way to distinguish between MWEs and compounds? On the basis of which criteria? Are there criteria that would hold crosslinguistically?

b) What kind of role do MWEs and compounds play in the construction of the lexicon? Is there competition between them?

These questions emerge quite naturally, given that both MWEs and compounds are, in a way, complex (multiword) lexical units. Yet, relatively little attention has been devoted to these specific issues, mainly because compounds and MWEs are topics that traditionally belong to different linguistic fields: morphology on the one hand, lexicology and phraseology on the other. In this paper I will address 
the matter by discussing data from Italian, with a view to contributing some answers to questions in a) and b) above.

First, I briefly describe the state of the art as far as Italian compounds and MWEs are concerned (Section 2). In Section 3 I address demarcation issues concerning compounding and MWEs. Section 4, instead, explores possible areas of competition between compounds and MWEs.

\section{Italian: a brief overview}

In this section I offer a (necessarily brief and sketchy) overview of Italian compounds and MWEs, which will serve as background knowledge for subsequent sections.

\subsection{Italian compounds}

Research on Italian compounding has by now a long-stading tradition (cf., among many others, Scalise 1992; Bisetto/Scalise 1999; Bisetto 2004; Ricca 2010; Masini/ Scalise 2012; Radimský 2015). Whereas, as widely known, compounding in Italian and Romance languages is not as productive as in Germanic languages, compounds are well-documented in these varieties. In what follows, I illustrate some basic facts about Italian compounds, taking into account the morphological type of the input elements, the lexical categories involved, and the relation among the constituents.

Typically, Italian compounds are made of full (sometimes inflected) words (1a), although we may also find stems (like verbal stems in VN compounds, cf. cava-in (1b)), as well as neoclassical formatives or semiwords (cf. (1c), where LV stands for 'linking vowel').

(1a) pesce-cane

fish-dog

'shark'

(1b) cava-tappi

extract-corks

'corkscrew'

(1c) crimin-o-logo

crime-LV-logist

'criminologist' 
Compounding in Italian productively feeds mostly the word classes of nouns (2) and adjectives (3), not verbs. As for input elements, productive patterns creating nouns and adjectives involve mostly nouns, adjectives and verbs, secondarily prepositions, as showed in (2)-(3) (where the head is underlined, when present). ${ }^{1}$

(2) Productive compound nouns

(2a) NA carro armato

cart armed

'tank'

(2b) N agenzia viaggi

agency travels

'travel agency'

(2c) VN asciuga-mani

dry-hands

'towel'

(2d) PN dopo-guerra

after-war

'post war period'

(3) Productive compound adjectives

(3a) AN giallo oro

yellow gold

'golden yellow'

(3b) $\underline{\mathrm{AA}}$ marxista-leninista

Marxist-Leninist

'Marxist-Leninist'

(3c) VN salva-spazio

save-space

'space-saving'

As far as the classification of compounds is concerned, Italian displays all six classes identified by Scalise/Bisetto (2009), as summarized in Table 1 (taken from Masini/Scalise 2012: 77).

1 These observations are taken from Masini/Scalise (2012). Patterns with semiwords are not included. 
Table 1: Classes of Italian compounds

\begin{tabular}{|c|c|c|c|}
\hline & Subordinate & Attributive & Coordinate \\
\hline Endocentric & $\begin{array}{l}\text { capo-stazione } \\
\text { (chief-station) } \\
\text { 'stationmaster' } \\
\text { transporto latte } \\
\text { (transportation milk) } \\
\text { 'milk transportation' }\end{array}$ & $\begin{array}{l}\text { cassa-forte } \\
\text { (case/box-strong) } \\
\text { 'safe' } \\
\text { viaggio lampo } \\
\text { (journey lightening) } \\
\text { 'very fast journey' }\end{array}$ & $\begin{array}{l}\text { poeta pittore } \\
\text { (poet painter) } \\
\text { 'poet painter' } \\
\text { divano-letto } \\
\text { (sofa bed) } \\
\text { 'sofa bed' }\end{array}$ \\
\hline Exocentric & $\begin{array}{l}\text { porta-lettere } \\
\text { (carry-letters) } \\
\text { 'mailman' } \\
\text { sotto-scala } \\
\text { (under-stairway) } \\
\text { 'closet under the stairway' }\end{array}$ & $\begin{array}{l}\text { viso pallido } \\
\text { (face pale) } \\
\text { 'facepale' } \\
\text { piedi piatti } \\
\text { (feet flat) } \\
\text { 'cop' }\end{array}$ & $\begin{array}{l}\text { Emilia Romagna } \\
\text { (Emilia Romagna) } \\
\text { 'Emilia Romagna' } \\
\text { dormi-veglia } \\
\text { (sleep-wake) } \\
\text { 'drowsiness' }\end{array}$ \\
\hline
\end{tabular}

It is worth noting that $\mathrm{NN}$ compounds encode the highest number of relations among the constituents, since they may be attributive (ATT), coordinate (CRD) and subordinate (SUB):

(4) Classes of NN compounds

$\begin{array}{lll}\text { (4a) } & \text { ATT } & \begin{array}{l}\text { pesce spada } \\ \text { fish sword }\end{array} \\ \text { 'sword fish' } & \text { CRD } \begin{array}{l}\text { divano letto } \\ \text { sofa bed } \\ \text { 'sofa bed' } \\ \text { nord-est } \\ \text { North-East }\end{array} \\ \text { (4c) } \quad \text { CRD } & \begin{array}{l}\text { 'North-East' } \\ \text { vendita latte } \\ \text { sale milk } \\ \text { 'milk shop' } \\ \text { (4d) } \quad \text { SUenzia viaggi } \\ \text { agency travels } \\ \text { (4e) } \quad \text { 'travel agency' }\end{array}\end{array}$

In attributive NN compounds (4a), the non-head expresses a property of the head noun (often via some metaphorical mechanism), despite not being an adjective. Coordinate (CRD) NN compounds may have two semantic heads (see (4b), where 
divano letto is both a sofa and a bed, hence a hyponym of both its input elements), or no internal head at all, like in nord-est (4c). Subordinate (SUB) NN compounds also comprise two subtypes, depending on the nature of the head noun, that may be deverbal (like vendita in (4d)) or not (like agenzia in (4e)).

Finally, one should note that Italian displays at least three productive patterns of exocentric compounds: coordinate NN compounds (cf. (4c)), PN compounds (cf. (2d)) and VN compounds, giving rise both to nouns (2c) and adjectives (3c). The latter is one of the most productive types of compounds in contemporary Italian (cf. Ricca 2010). Hence, exocentricity is well-attested in Italian compounding.

\subsection{Italian MWEs and phrasal lexemes}

Multi-word expression is widely used as an umbrella term to refer to a large set of linguistic objects (cf. Baldwin/Kim 2010 and Hüning/Schlücker 2015 for an overview), including verbal idioms (5a) and other kinds of idiomatic expressions (e.g. (5b)), sayings (5c), lexicalized sentences (5d), formulae (5e), complex nominals (5f), irreversible binomials (5g), verb-particle constructions (5h) and other complex predicates such as light verb constructions (5i).

(5a) $\begin{aligned} & \text { alzare il gomito } \\ & \text { raise the elbow } \\ & \text { 'to drink too much' } \\ & \text { fuori di testa } \\ & \text { out of head } \\ & \text { 'out of one's mind' } \\ & \text { (5b) dire mai } \\ & \text { (5c) nai never } \\ & \text { 'never say never' } \\ & \text { fai-da-te } \\ & \text { (5d)-from-you } \\ & \text { 'do-it-yourself' } \\ & \text { stai scherzando? } \\ & \text { stay.2.sG joking } \\ & \text { 'Are you kidding me?' } \\ & \text { (5emi di distruzione di massa } \\ & \text { weapons of destruction of mass } \\ & \text { 'weapons of mass destruction' }\end{aligned}$
(5f) 


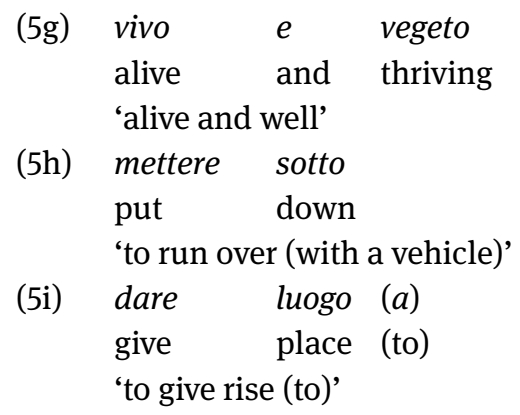

Most of these expressions have been investigated separately from word formation, and within other scholarly traditions. Idioms and collocations, for instance, are typically the realm of phraseology (cf., e.g., Cowie (ed.) 1998) and corpus linguistics (cf., e.g., Moon 1998), but also psycholinguistics (cf., e.g., Cacciari/ Tabossi (eds.) 1993) and syntax (cf., among others, Everaert et al. (eds.) 1995).

Morphologists, on the other hand, have always devoted little attention to these multiword phenomena. A notable exception regards complex predicates (cf., e.g., Butt 1995, Ackerman/Webelhuth 1997) - in particular verb-particle constructions in Germanic (cf., e.g., Dehé et al. (eds.) 2002) but also Romance (cf. Iacobini/Masini 2007; cf. also below) languages.

Recently, morphologists have started devoting more attention to this area, especially within the framework of Construction Morphology (Booij 2010; henceforth CxM). This is little surprising - as also observed by Hüning/Schlücker (2015) - given that CxM is linked to Construction Grammar (Hoffmann/Trousdale (eds.) 2013; henceforth $\mathrm{CxG}$ ), a model whose foundations lie on studies on idiomatic structures, from Fillmore/Kay/O'Connor (1988) onwards.

In CxM, both words and word formation patterns are seen as 'constructions', i.e. conventionalized form-meaning pairings: morphological constructions may differ in size, complexity and schematicity, and are organized into a hierarchical lexicon. Besides, units that are larger than a morphological word but nonetheless conventionalized and stored into our lexicon are also regarded as constructions, as complex signs. Indeed, CxM has originated from work on phenomena inbetween morphology and syntax, in particular separable complex verbs in Dutch, which have been treated as a case of 'periphrastic word formation' by Booij (2002b).

In other words, within $\mathrm{CxG}$ and $\mathrm{CxM}$, MWEs are seen as part of our lexicon, as anticipated in Section 1. Some MWEs have the same distribution of sentences (sayings) or full VPs (idiomatic expressions); formulaic expressions may also 
serve as full utterances (but note that formulae may be constituted also by one single word). Some other MWEs, in particular those that have been called phrasal lexemes or lexical phrases (Booij 2009a, 2010; Masini 2009, 2012) are closer than other MWEs to morphological words (especially compounds), hence I will mainly focus on these.

Phrasal lexemes are those MWEs that are closest to words in terms of both distribution and function, i.e., they have a word-like distribution (so sentence-level MWEs would not be phrasal lexemes) and they have the same concept-naming function of words, thus contributing to lexical enrichment (cf. Masini 2012). They correspond to various patterns and can in principle belong to all lexical categories, at least in Italian, e.g.: nouns (6a), adjectives (6b), verbs (6c), adverbs (6d), prepositions (6e), conjunctions (6f), interjections (6g), pronouns (6h).

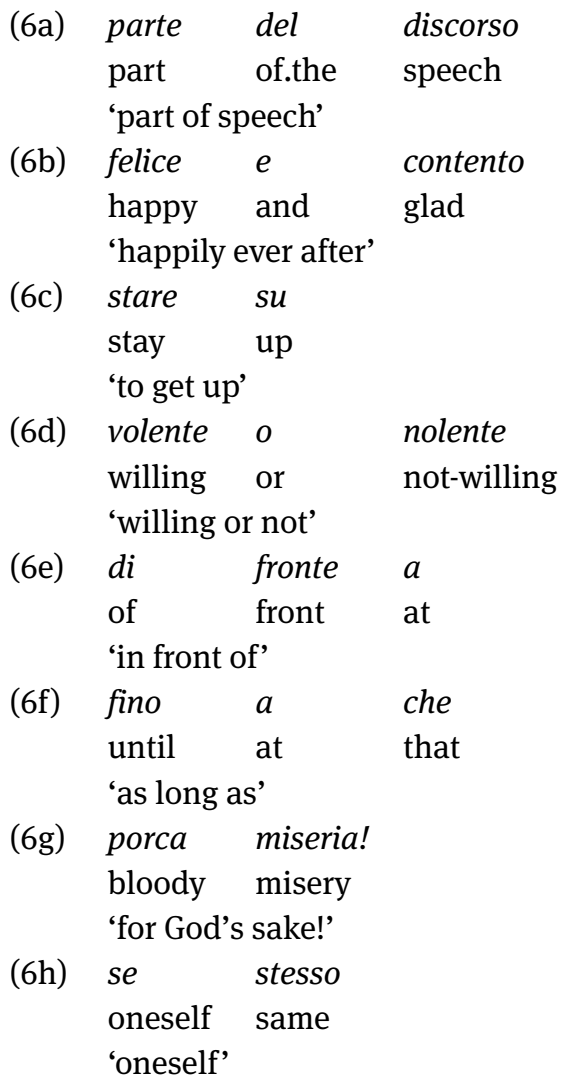


These items are not words in the proper sense, since they have a phrase-like structure; some of them may even be separable under certain conditions. ${ }^{2}$ At the same time, however, they present a unitary, often conventionalized semantics, and display a higher degree of internal cohesion than free phrases.

As an example, let us take phrasal lexemes that belong to the noun category, i.e., phrasal nouns. ${ }^{3}$ Italian presents a variety of patterns that fill this class (cf. Masini 2012), including:

\begin{tabular}{|c|c|c|c|c|}
\hline (7a) & NPN & $\begin{array}{l}\text { casa } \\
\text { home }\end{array}$ & $\begin{array}{l}d i \\
\text { of }\end{array}$ & $\begin{array}{l}\text { riposo } \\
\text { rest }\end{array}$ \\
\hline & & 'nursing & nome, ho & spice’ \\
\hline (7b) & NPArtN & $\begin{array}{l}\text { parte } \\
\text { part }\end{array}$ & $\begin{array}{l}\text { del } \\
\text { of.the }\end{array}$ & $\begin{array}{l}\text { discorso } \\
\text { speech }\end{array}$ \\
\hline & & 'part of ss & beech' & \\
\hline (7c) & NA & $\begin{array}{l}\text { anno } \\
\text { year }\end{array}$ & $\begin{array}{l}\text { accaden } \\
\text { academ }\end{array}$ & \\
\hline & & 'academi & c year’ & \\
\hline (7d) & AN & $\begin{array}{l}\text { prima } \\
\text { first }\end{array}$ & $\begin{array}{l}\text { serata } \\
\text { evening }\end{array}$ & \\
\hline & & 'prime tin & & \\
\hline (7e) & NConjN & $\begin{array}{l}\text { coltello } \\
\text { knife } \\
\text { 'cutlery' }\end{array}$ & $\begin{array}{l}e \\
\text { and }\end{array}$ & $\begin{array}{l}\text { forchetta } \\
\text { fork }\end{array}$ \\
\hline
\end{tabular}

Phrasal nouns of the NP(Art)N type, for instance, look like normal noun phrases (formed by a noun plus a prepositional phrase), but are more cohesive than free phrases: indeed, they generally resist various operations (with some variation)

2 This is especially true of verbal expressions: stare su (6c), for instance, may be interrupted by a light adverb, e.g. stai subito su! (lit. stay immediately up) 'get up immediately!'. On this topic cf. Voghera (2004), who claims that the (different) degree of cohesiveness displayed by these expressions partially depends on the lexical category they belong to, with prepositional and conjuctional phrasal lexemes being more cohesive than adverbial and adjectival ones, the latter being more cohesive than nominal ones, whereas verbal expressions are the least cohesive of all. 3 These items have been named in many different ways in the literature, including, e.g., "phrasal compounds" / "prepositional compounds” (Delfitto/Melloni 2009; Rio-Torto/Ribeiro 2009), and "improper compounds" (Rainer/Varela 1992). The distinction between phrasal nouns and compound nouns is not always trivial, as we will see in Section 3.

4 Coordinate phrasal nouns can also be formed by two verbs, e.g. va e vieni (lit. go and come) 'coming and going / toing and froing' (cf. Masini/Thornton 2008). 
including interruption (8a), insertion of determiners (8b) or paradigmatic substitution (8c) (cf. Masini 2009 for more details).

(8) casa di riposo (lit. home of rest) 'retirement home, hospice'

(8a) ${ }^{\star}$ casa rinomata di riposo

home renown of rest

Intended reading: 'renown retirement home'

(8b) ${ }^{\star}$ casa riposo

home of.the rest

Intended reading: 'retirement home'

(8c) *abitazione di riposo

dwelling of rest

Intended reading: 'retirement home'

What is crucial about these items is that they are not just univerbations or lexicalized phrases that emerge diachronically. Some certainly are, but a number of them are actually neologisms productively created by speakers to name new concepts. Sometimes, they are calques from other languages. Take for instance the three following examples, from the ONLI database: ${ }^{5}$

(9a)

$\begin{array}{lll}\text { cibo } & \text { di } & \text { strada } \\ \text { food } & \text { of } & \text { street }\end{array}$

'street food'

(9b) popolo della rete

people of.the Internet

'people who use the Internet'

(9c) città digitale

town digital

'a town endowed with digital technology that inhabitants can use to access public information and services’

Cibo di strada (9a) is a calque from English street food which is however rendered in Italian with a NPN phrasal noun rather than a NN compound, which possibly points to the higher availability of the former type. Popolo della rete and città digitale are new coinages that have been introduced into the Italian language by exploiting the NPArtN and NA patterns, respectively. All examples in (9) are there-

5 Osservatorio Neologico della Lingua Italiana: www.iliesi.cnr.it/ONLI (last access: 11.6.2018). 
fore conventionalized phrasal nouns with a naming function. Although wide-ranging quantitative data are still unavailable, it is reasonable to think that phrasal nouns constitute a significant part of neologisms in contemporary Italian. In this respect, it is useful to remind that Émile Benveniste claimed, already in 1966, that NPN is the true, productive compounding pattern in French (called by the author "synapsie”, e.g. clair de lune lit. light of moon 'moonlight', moulin à vent lit. mill at wind 'windmill').

In addition to nouns, Italian has a variety of phrasal means to form complex predicates. This is important in view of the fact that Italian lacks verbal compounding altogether; therefore, multiword verb formation may be seen as a way to compensate this part of the Italian lexicon. There are two patterns that are especially prominent in this domain: verb-particle constructions and light verb constructions. As is well-known by now, Italian, despite being a Romance language, also has particle verbs (e.g., Masini 2005, Iacobini/Masini 2007, Iacobini 2015), although the phenomenon is not as pervasive as in English (see (10)). Also light verb constructions are quite widespread (11): they are formed by a light, generic verb plus a predicative noun (cf., e.g., Jezek 2004).

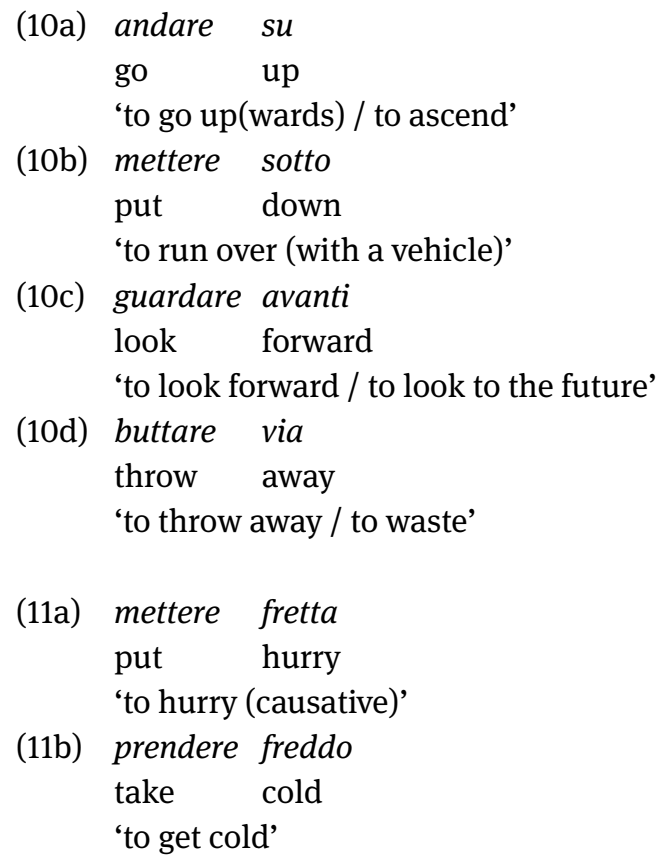




$\begin{array}{lll}\text { (11c) } & \begin{array}{l}\text { avere paura } \\ \text { have fear } \\ \text { 'to be afraid' }\end{array} & \\ \text { (11d) } & \begin{array}{l}\text { dare vita } \\ \text { give life }\end{array} \\ & \text { (a) } \\ \text { 'to create' }\end{array}$

Since phrasal lexemes (and other MWEs) can be seen as constructions within $\mathrm{CxM}$ - exactly like simple and complex words, as well as word formation schemas and subschemas - we expect them to interact in various ways with word-formation processes. Hüning/Schlücker (2015) claim that "MWEs and compounds are largely a complementary means for creating lexical units". In Section 4, I offer some data and reflections about the relationship between these two strategies in terms of competition. Before that, however, it is necessary to discuss some demarcation issues.

\section{Demarcation issues}

Starting from the idea that we have two sets of complex lexical constructions that are used to form stable (stored), complex denotations in the world's languages, namely compounds and MWEs, we may ask if they can actually be distinguished, and on which ground. In addition, we may want to ask whether their demarcation is clear-cut or not in every language, and if the criteria to be used are valid crosslinguistically. The expectation is that crosslinguistic validity is hardly achievable, since the demarcation between compounds and MWEs ultimately has to do with the demarcation between morphology and syntax, between words and phrases, which is a well-known, unsolved question, especially in a typological perspective (cf., e.g., Haspelmath 2011).

Compounds as purely morphological objects have been defined by Guevara/ Scalise (2009: 108) as complex words formed by two (or more) words whose general structure is captured by the formula in (12). Let us take this operational definition as a starting point for our discussion.

$[\mathrm{X} \Re \mathrm{Y}]_{\mathrm{Z}}$ where $\mathrm{X}, \mathrm{Y}$ and $\mathrm{Z}$ represent major lexical categories, and $\mathfrak{R}$ represents an implicit relationship between the constituents (a relationship not spelled out by any lexical item) 
First, it is interesting to note that, according to (12), compound words should belong to major lexical categories only, i.e. to open classes that can be synchronically enriched with new members. As we have seen in Section 2, phrasal lexemes in Italian can also belong to minor lexical categories. Hence, this is one possible difference between compounds and MWEs in Italian (not necessarily valid in every language). However, MWEs belonging to minor lexical categories (prepositions, conjunctions, etc.) are basically the result of a diachronic process of lexicalization or univerbation, whereas at least some of the MWEs belonging to major lexical categories seem to result from a synchronic process of lexical creation. Therefore, synchronically speaking, both compounds and MWEs feed the same (open) classes (as is natural to expect).

Second, not all major lexical categories are equally fed by compounding and MWEs: languages differ in this respect. In Italian, compounds are mostly nouns (which is also the primary input category) and secondarily adjectives, whereas compound verbs and adverbs are basically absent. MWEs, on the other hand, feed also verbs and adverbs.

Third, the restriction to lexical categories implies that higher level structures (e.g. sentences) are excluded from compounding (obviously so), whereas we know that some MWEs may coincide with full sentences and utterances (e.g. sayings and formulaic expressions) or full VPs (cf. especially verbal idioms, e.g. like mettere le mani avanti lit. put the hands forward to prevent an unpleasant situation').

So, overall, we can conclude that in Italian (and possibly other languages) compounds and MWEs have a partially different distribution: whereas compounds function as word-level elements, MWEs may also correspond to full phrases and even sentences. Of course, there is a subset of MWEs - named here phrasal lexemes - that are closer to compounds in that, as anticipated in Section 2.2, they: i) have the same concept-naming function of compounds and words in general; ii) have the same distribution of a word (e.g. carta di credito 'credit card', which functions syntactically like a noun, with which it may be substituted: pagare con la carta di credito 'to pay with credit card' vs. pagare con i contanti 'to pay with cash').

Then, how can we distinguish compounds and phrasal lexemes in Italian?

Let us concentrate on phrasal nouns, since noun is the preferred output category for Italian compounding (but also crosslinguistically: cf. Guevara/Scalise 2009). Before focusing on Italian, I briefly discuss some examples from various languages that are meant to illustrate some of the criteria proposed in the literature to distinguish between compound nouns and phrasal nouns. 
In Dutch, AN compounds and AN phrasal lexemes can be formally distinguished since the latter display agreement inflection on the adjective (see the suffix -e in (13a-b)), ${ }^{6}$ whereas the former do not (13c-d) (cf. Booij 2009a).

(13a) donker-e kamer (Dutch) 'dark room'

(13b) mager-e yoghurt 'fat-free yoghurt'

(13c) fijn-stof 'fine-grained dust'

(13d) vroeg-geboorte 'premature birth'

German works very similarly (cf. Schlücker/Hüning 2009): like in Dutch, in German AN compounds, the adjective is not inflected, bears the main stress and is generally monomorphemic (14a), whereas in AN phrasal lexemes the adjective is inflected, does not bear the main stress, and can be complex (cf. (14b-c)).

(14a) Rot-wein

(German) 'red wine'

(14b) werdende Mutter 'mother-to-be'

(14c) werdender Vater 'father-to-be'

In Russian, phrasal nouns display regular agreement (15a) or government (15b) among the constituents (which are independent words), whereas compounds do not, since the first member is typically a root (hence a bounded element) connected to the second constituent by a linking vowel (16) (cf. Masini/Benigni 2012).

$\begin{array}{lll}\text { (15a) } & \begin{array}{l}\text { suchoe } \\ \text { dry.NOM.SG.NEUT } \\ \text { 'powdered milk' }\end{array} & \text { moloko } \\ \text { milk.NOM.SG.NEUT } \\ \text { (15b) } \begin{array}{ll}\text { točka } \\ \text { point.NOM.SG.F } \\ \text { 'point of view' }\end{array} & \text { zrenija } \\ & \text { view.GEN.SG.NEUT }\end{array}$

(Russian)

6 As Booij (2009a: 224) states, “[t]he pre-nominal adjective ends in the suffix -e, unless the NP is indefinite and the head noun is singular and neuter (in the latter case the ending is zero)”. 
(16) sux-o-frukty

(Russian)

dry-LV-fruit.M.PL.NOM

'dry fruit'

Quite expectedly, the criteria vary from language to language, depending on language-specific properties. Some criteria may be shared by more than one language (e.g. Dutch and Russian share the loss of agreement inflection, although the phenomenon is more consistent in Russian), whereas others may not (e.g. Russian linking vowels can be used to distinguish compounds from phrases, but not all languages feature these items). Furthermore, some criteria are themselves questionable: it is not clear, for instance, whether "semantic transparency" would be a reliable criterion, as we will discuss below.

What about Italian? How can we say, for instance, that the expressions in (17) are phrasal nouns and not compounds?

\begin{tabular}{|c|c|c|c|}
\hline (17a) & $\begin{array}{l}\text { cart-a } \\
\text { card-F.SG } \\
\text { 'phone card' }\end{array}$ & $\begin{array}{l}\text { telefonic- } a \\
\text { of_the_phone-F.SG }\end{array}$ & {$[\mathrm{NA}]_{\mathrm{N}}$} \\
\hline (17b) & $\begin{array}{l}\text { terz-o } \\
\text { third-M.SG } \\
\text { 'Third World' }\end{array}$ & $\begin{array}{l}\text { mond-o } \\
\text { world-M.SG }\end{array}$ & {$[\mathrm{AN}]_{\mathrm{N}}$} \\
\hline (17c) & $\begin{array}{l}\text { casa di } \\
\text { house of } \\
\text { 'nursing home' }\end{array}$ & $\begin{array}{l}\text { cura } \\
\text { treatment }\end{array}$ & {$[\mathrm{NPN}]_{\mathrm{N}}$} \\
\hline$(17 d)$ & $\begin{array}{ll}\text { botta } & e \\
\text { blow } & \text { and }\end{array}$ & $\begin{array}{l}\text { risposta } \\
\text { answer }\end{array}$ & {$[\mathrm{NConjN}]_{\mathrm{N}}$} \\
\hline
\end{tabular}

It seems to me that the following criteria might be used for Italian, taking the definition in (12) and lexical integrity as reference points:

(18a) internal agreement (absent in compounds, present in phrasal lexemes);

(18b) explicit relational markers, such as conjunctions and prepositions (absent in compounds, present in phrasal lexemes);

(18c) minor lexical categories, such as articles (absent in compounds, present in phrasal lexemes);

(18d) bounded elements, such as roots/stems or linking vowels (present in compounds, absent in phrasal lexemes). 
Agreement in number and gender is present in (17a) and (17b), as shown by the glosses. The presence of explicit relational markers is displayed by both (17c) (preposition $d i$ 'of') and (17d) (conjunction $e$ 'and'). The presence of minor lexical categories is shown by the examples in (19): in (19a) the two nouns are linked by a preposition with article (della 'of the' $=d i$ 'of' $+l a$ 'the.F.SG'), whereas in (19b) we have a lexicalized expression containing an article. Finally, bounded elements show up in compounds only (cf. Section 2.1). ${ }^{7}$

$\begin{array}{lll}\text { (19a) } \begin{array}{lll}\text { macchina } \\ \text { machine } \\ \text { 'lie detector' } \\ \text { cessate }\end{array} & \begin{array}{l}\text { della } \\ \text { of.the }\end{array} & \begin{array}{l}\text { verità } \\ \text { truth }\end{array} \\ \begin{array}{l}\text { cease.IMP.PL } \\ \text { 'ceasefire' }\end{array} & \text { the } & \begin{array}{l}\text { fuoco } \\ \text { fire }\end{array}\end{array}$

It is worth noting that the proposed criteria are formal, not semantic. Bisetto (2004) proposes a semantic criterion to distinguish between compounds and so-called polirematiche (an Italian standard term for phrasal lexemes): compounds would be the result of a productive process, thus tending to be hyponyms of their heads, whereas polirematiche would arise from lexicalization and thus typically display a non-compositional meaning. In our view, this semantic criterion is not really deciding: on the one hand, we may have compounds that are formed productively and can be readily interpreted by the hearer (cf. (20a), where capostazione is actually a type of capo) and compounds that are more lexicalized and whose semantics is not as transparent (20b); on the other hand, phrasal nouns may either be created on the basis of a productive and interpretable pattern (21a) or arise from lexicalization or idiomatization of a phrase (21b).

\section{(20a) capo-stazione head-station 'stationmaster'}

\footnotetext{
7 A possible counterexample would be the phrasal lexemes with two coordinated verbs mentioned in footnote 4 (e.g. va e vieni lit. go and come 'coming and going'). As argued by Masini/ Thornton (2008), the verbal forms used in these expressions are homophonous to the $2^{\text {nd }}$ person singular imperative, exactly like the verbal forms occurring within VN compounds. If we analyze this verbal form as some sort of morphomic stem used in Italian morphology, we end up with a clash: use of a bounded form on the one hand, and presence of an explicit relational marker $(e$ 'and') on the other.
} 
(20b) capo-cielo

head-sky

'canopy erected over a high altar'

(21a) mulino a vento

mill at wind

'windmill'

(21b) luna di miele

moon of honey

'honeymoon'

The application of the criteria proposed above is not always straightforward and may produce unexpected results. Take for instance the agreement criterion. This is pretty efficient in Dutch and Russian, but less so in Italian, since agreement takes place in virtually all combinations of a noun and an adjective. This means that even an expression like croce-rossa (cross.F.SG-red.F.sG) 'Red Cross', which is traditionally regarded as a compound in the literature (like many others, e.g., cassaforte 'safe' in Table 1), should instead be considered as a phrasal lexeme by this criterion, exactly like carta telefonica and terzo mondo in (17a-b).

Along these lines, one may argue that also "internal inherent inflection" (i.e. inflectional marking occuring inside the word, not triggered by agreement, such as number for nouns) should be considered as a criterion to be added to the list in (18). Also in this case, we would end up regarding many Italian items (traditionally analyzed as compounds) as phrasal lexemes, such as left-headed NN compounds of the capostazione type (20a), in which the plural marker applies to the left (head) constituent: capo-stazione (lit. head-station) 'stationmaster' turns into capi-stazione (lit. heads-station) 'stationmasters', and not *capo-stazioni (head-stations), with plural marker on the right (as we would expect from a "true word"). However, we can also observe that, despite internal inflection, capostazione is still (at least partly) compound-like due to the absence of any relational element (see criterion (18b)) between capo and stazione (cf. the corresponding phrasal expression capo della stazione lit. head of.the station). Therefore, the compound-phrasal noun demarcation may be a matter of degree rather than clear-cut (cf. also footnote 7): for instance, compounds that display no internal agreement and no internal (inherent) inflection (e.g. dopoguerra 'post war period' or asciugamani 'towel', cf. (2), Section 2.1) are more compound-like than capostazione (which is split by inflection in the plural). In other words, the concepts of compound and phrasal lexeme may be seen as prototypes, or radial categories, that can be defined on the basis of a complex interaction of properties, rather than on a set of necessary and sufficient features. 
All in all, based on the observations above, one may note that the demarcation between noun compounds and phrasal nouns in Italian largely relies on criteria that typically distinguish words from phrases, with the complication that phrasal nouns are not free, full-fledged phrases. ${ }^{8}$ As is well-known, word(hood) is far from being a simple concept with crosslinguistic validity (Haspelmath 2011). However, CxM assumes that "cohesiveness is the defining criterion for canonical wordhood” (Booij 2009b: 97). And cohesiveness obviously manifests itself in different ways in different languages, depending on the morphological and syntactic properties of the language in question. So, the exact criteria to be used should be identified on a language-specific basis, but the same general principle applies.

Given these premises, we might expect to have languages in which the formal differences between compounds and phrasal lexemes are evident and easily detectable (e.g. Russian, i.e. a language where compounds are mostly root-compounds), languages in which these are vague or even non-existent (e.g. English, where it is very difficult to state whether conventionalized AN combinations such as black board are compounds or phrases, cf. Giegerich 2005, 2009), and languages, such as Italian, that are in-between, since they offer at least some evidence in favor of maintaining such a division.

In conclusion, we may regard the demarcation between compounds and phrasal lexemes as an element of variation among the languages of the world that possibly correlates with their morphological type: with the limited data gathered so far, we may hypothesize that this demarcation is clearer in highly inflectional languages displaying root compounding, whereas in isolating languages the boundary is definitely more blurred, if not absent.

\section{Competition issues}

Competition in morphology and the lexicon is generally viewed as a relation holding between different word-level strategies that compete to realize the same grammatical or lexico-conceptual meaning. However, recent work has claimed that morphological words also compete with MWEs (Booij 2010; Hüning/Schlücker 2015; Masini 2016, to appear). The relationship between morphological words and MWEs, however, is still underinvestigated and calls for further research.

8 The following general properties keep phrasal lexemes apart from true, free phrases: greater internal cohesion, paradigmatic fixedness (i.e., they resist lexical substitution) and conventionalized (though not necessarily idiomatic) meaning (cf. Section 2.2, example (8)). 
In this section I show that competition between compounds and MWEs may result in the blocking of specific lexical items, and that these blocking effects may operate in both directions. ${ }^{9}$ More specifically, I briefly illustrate three case-studies regarding the competition between compounds and phrasal lexemes in the nominal domain, namely: i) NP(Art)N phrasal nouns (e.g. macchina della verità 'lie detector') in comparison with NN compounds (e.g. capostazione 'stationmaster') (Section 4.1); ii) the simile construction with color adjectives (e.g. rosso come il fuoco lit. red as the fire 'red as fire') in comparison with the corresponding compound pattern (e.g. rosso fuoco lit. red fire 'fire-like red') (Section 4.2); iii) irreversible binomials (e.g. sano e salvo 'safe and sound') as compared with coordinate compounds of the sordomuto 'deaf-mute' type (Section 4.3).

\subsection{Complex nominals: NP(Art)N phrasal nouns vs. NN compounds}

NN compounding is attested in Romance languages, including Italian (cf., e.g., Masini/Scalise 2012, Radimský 2015). At the same time, we have NP(Art)N phrasal nouns (cf. Section 2), which are another productive way to form complex nominals in Romance languages (especially - but not exclusively - in special languages), as already noted by Benveniste (1966) for French (cf. also Voghera 2004 and Masini 2009 for Italian; Bernal 2012 for Catalan; Rio-Torto/Ribeiro 2012 for Portuguese). See some examples below.

$\begin{array}{llll}\text { (22a) } \begin{array}{l}\text { giacca a vento } \\ \text { jacket at }\end{array} & \begin{array}{l}\text { (Italian) } \\ \text { 'windbreaker' }\end{array} & \\ \text { (22b) } \begin{array}{l}\text { moulin à } \\ \text { mill at }\end{array} & \begin{array}{l}\text { vent } \\ \text { wind }\end{array} & \text { (French) } \\ \text { 'windmill' } & & \\ \text { (22c) } \begin{array}{l}\text { mal de cap } \\ \text { pain of }\end{array} & \text { head } & \text { (Catalan) } \\ \text { 'headache' } & & \\ \text { (22d) } \begin{array}{l}\text { cadeira de } \\ \text { chair of odas } \\ \text { 'wheelchair' }\end{array} & \text { wheels } & \text { (Portuguese) }\end{array}$

9 For a broader picture of the competition between MWEs and all kinds of morphological words, including simple words and derived words, cf. Masini (2016, to appear). 
Given that NN compounds and NP(Art)N phrasal nouns coexist in Italian, and that both are used to coin new complex nominals, competition between these two patterns is likely to emerge. As a case-study, let us consider Italian NN compounds where capo 'head, boss' is the head (leftmost) constituent. This pattern of compounding is pretty productive in Italian and is associated with the meaning 'head/boss of N'. ${ }^{10}$
(23a) capo-stazione
head-station
'stationmaster'
(23b) capo-classe
head-class
'class president'
(23c) capo-gruppo
head-group
'group leader'
(23d) capo-famiglia
head-family
'head of the family'

Other possible capo+N compounds could be:
(24a) ${ }^{\circ}$ capo-stato
head-state
(24b) ${ }^{\circ}$ capo-governo
head-government
(24c) ${ }^{\circ}$ capo-polizia
head-police

However, these perfectly well-formed items are not actually produced (the ${ }^{\circ}$ sign marks well-formed but non-existent expressions). The reason for this is that they are blocked by already existing NPN phrasal nouns featuring the same constituent words, namely:

10 Note that not all capo $+\mathrm{N}$ compounds have this semantics: some mean 'chief N', such as caporedattore (lit. head-editor) 'editor in chief'. 


$\begin{array}{lll}\text { (25a) } \begin{array}{l}\text { capo dello } \\ \text { head of.the }\end{array} & \begin{array}{l}\text { stato } \\ \text { state }\end{array} \\ \text { 'head of state' } & \\ \text { (25b) } & \begin{array}{l}\text { capo del } \\ \text { head of.the }\end{array} & \begin{array}{l}\text { governo } \\ \text { government }\end{array} \\ \text { 'Prime Minister' } & \\ \text { (25c) } & \begin{array}{l}\text { capo della } \\ \text { head of.the }\end{array} & \text { polizia } \\ & \text { police } \\ & \text { 'chief of police' }\end{array}$

The reverse may also occur: for instance, the expression capo della classe (26) is perfectly grammatical and interpretable as 'class president'; however, it is not used with this specific intended reading, because the same meaning is already conveyed by the established compound capoclasse (cf. (23b)).

(26) capo della classe
head of.the class
'class president'

This type of competition in Italian can be compared to a similar case in Dutch and German. In these languages, AN combinations could be realized either as phrasal nouns (cf. (27a), (28a)) or as compounds (cf. (27b), (28b)) (cf. Booij 2009a, 2010 for Dutch; Hüning/Schlücker 2015 for German; cf. also Section 3). If we try to create the corresponding combination (cf. (27a'-b'), (28a'-b')), we get a possible but non-existent or non-conventionalized expression (in the intended reading).

(27a) grüne Welle (lit. green wave) 'progressive signal system'

(German)

(27a') ${ }^{\circ}$ Grünwelle

(27b) Dunkelkammer 'darkroom'

(27b’) dunkle Kammer

(28a) wilde gans (lit. wild goose) 'brant'

(Dutch)

(28a') ${ }^{\circ}$ wildgans

(28b) sneltrein (lit. fast-train) 'express train'

(28b') ${ }^{\circ}$ snelle trein

These data may be interpreted either as cases of lexical blocking (Rainer 2016) (token blocking in Rainer 1988) or rather as an effect of a more general tension between two competing patterns, namely, in the Italian case, between NN com- 
pounding on the one hand and $\mathrm{NP}(\mathrm{Art}) \mathrm{N}$ phrasal lexemes on the other. Both views are viable in a constructionist view of morphology and the lexicon, where constructions are arranged into an inheritance hierarchy where abstract schemas generalize over more specific constructions. Hence, which type of blocking is actually at work is an empirical question.

\subsection{Complex color expressions: simile constructions vs. compounds}

In many languages we find simile constructions with an intensifying meaning headed by an adjective of the type exemplified in (29) for English (cf. Kay 2013) and (30) for German (cf. Hüning/Schlücker 2015, Schlücker this volume). Most are conventionalized and qualify as MWEs.

(29) [A as NP]

(29a) dead as a doornail 'quite dead'

(English)

(29b) light as a feather 'extremely light'

(29c) flat as a pancake 'completely flat'

(30) $[($ so) A wie NP]

(30a) (so) weiß wie Schnee '(as) white as snow'

(German)

(30b) (so) flink wie ein Wiesel '(as) quick as a flash'

(30c) (so) schlank wie eine Gerte '(as) slender as a whip'

A very similar pattern is found in Italian, where come corresponds to as and wie:

(31) [A come NP]

$\begin{array}{llll}\text { (31a) vecchio } & \text { come } & \text { il } & \text { mondo } \\ \text { old } & \text { as } & \text { the } & \text { world }\end{array}$

(31b) bello come il sole

beautiful as the sun

'very beautiful'

(31c) liscio come l' olio

smooth as the oil

'very smooth' 
If we search the [A come NP] pattern in a large corpus ${ }^{11}$ and rank the results for frequency, what we find is that many of the top ranked occurrences contain a color term (32), most notably nero 'black', bianco 'white' and rosso 'red' (but also other colors, e.g. azzurro 'light-blue', giallo 'yellow', blu 'blue', verde 'green'). The simile construction with color terms apparently retains the intensification meaning associated with the general [A come NP] construction.

(32) $\left[\mathrm{A}_{\text {COLOR }}\right.$ come NP]

$\begin{array}{llll}\text { (32a) } \begin{array}{l}\text { nero come la } \\ \text { black as } \\ \text { 'pitch black' }\end{array} & \begin{array}{l}\text { pece } \\ \text { the }\end{array} & \begin{array}{l}\text { pitch } \\ \text { (32b) bianco come la } \\ \text { white as } \\ \text { 'snow-white' }\end{array} & \begin{array}{l}\text { neve } \\ \text { snow }\end{array} \\ \text { (32c) } \begin{array}{l}\text { rosso come } \\ \text { red as al }\end{array} & \begin{array}{l}\text { sangue } \\ \text { the }\end{array} \\ & \text { blood red' }\end{array}$

Interestingly, some of the AN pairs occurring within the simile construction are also found as compounds in German, as noted by Hüning/Schlücker (2015):

\begin{tabular}{|c|c|c|c|c|c|}
\hline (33a) & $\begin{array}{l}\text { weiß } \\
\text { white }\end{array}$ & $\begin{array}{l}\text { wie } \\
\text { as }\end{array}$ & $\begin{array}{l}\text { Schnee } \\
\text { snow }\end{array}$ & & $\begin{array}{l}\text { s schneeweiß } \\
\text { 'snow-white' }\end{array}$ \\
\hline (33b) & flink & wie & ein & Wiesel & wieselflink \\
\hline & nimble & as & $\mathrm{a}$ & weasel & 'quick as a flash’ \\
\hline (33c) & $\begin{array}{l}\text { schlank } \\
\text { slender }\end{array}$ & $\begin{array}{l}\text { wie } \\
\text { as }\end{array}$ & $\begin{array}{l}\text { eine } \\
\mathrm{a}\end{array}$ & $\begin{array}{l}\text { Gerte } \\
\text { whip }\end{array}$ & $\begin{array}{l}\sim \text { gertenschlank } \\
\text { '((as) slender as a whip' }\end{array}$ \\
\hline
\end{tabular}

(German)

The same holds for Italian, but only for a subset of expressions, namely those containing a color adjective (34). Similar doublets are not found in Italian with other kinds of adjectives (cf. (35), corresponding to (31)).

11 The data for this analysis are taken from the Italian Web 2010 (or itTenTen10) corpus, a web corpus of approx. 2,5 billion words searched through the SketchEngine (www.sketchengine. co.uk, last access: March 2017). 


\begin{tabular}{|c|c|c|c|c|c|c|}
\hline (34) & {$\left[\mathrm{A}_{\text {COLOR }}\right.$ come } & NP] $M$ & $N E$ & & $\sim$ & {$\left[\mathrm{A}_{\text {COLOR }} \mathrm{N}\right]$ compo } \\
\hline (34a) & bianco & come & il & latte & $\sim$ & bianco latte \\
\hline & white & as & the & milk & & \\
\hline & 'milk-white' & & & & & \\
\hline (34b) & nero & come & il & carbone & $\sim$ & nero carbone \\
\hline & black & as & the & coal & & \\
\hline & 'coal-black' & & & & & \\
\hline (34c) & azzurro & come & il & cielo & $\sim$ & azzurro cielo \\
\hline & $\begin{array}{l}\text { light_blue } \\
\text { 'sky-blue' }\end{array}$ & as & the & sky & & \\
\hline (35a) & vecchio & come & il & mondo & $\sim$ & ${ }^{\star}$ vecchio mondo \\
\hline & old & as & the & world & & \\
\hline & 'very old' & & & & & \\
\hline (35b) & bello & come & il & sole & $\sim$ & ^bello sole \\
\hline & beautiful & as & the & sun & & \\
\hline & 'very beauti & iful' & & & & \\
\hline$(35 c)$ & liscio & come & l' & olio & $\sim$ & ^liscio olio \\
\hline & smooth & as & the & oil & & \\
\hline & 'very smoot & & & & & \\
\hline
\end{tabular}

Compounds of the $\left[\mathrm{A}_{\text {COLOR }} \mathrm{N}\right]$ type are relatively common in Italian (cf. D'Achille/ Grossmann 2010, 2013). The color A is the head of the compound (and is generally invariable), whereas the $\mathrm{N}$ serves as a modifier: more precisely, it denotes a referent that typically exemplifies the shade of the color in question. The expression giallo canarino (lit. yellow canary), for instance, denotes a kind of yellow that is typically exemplified by canary birds.

Therefore, we have a domain, that of complex color adjectives, where there seem to be two competing strategies that form expressions with similar content: $\left[\mathrm{A}_{\text {COLOR }}\right.$ come $\left.\mathrm{NP}\right]$ multiword simile constructions and [ $\left.\mathrm{A}_{\text {COLOR }} \mathrm{N}\right]$ compounds. How much do they actually overlap?

In order to answer this question, I generated frequency lists of both the [ $A_{\text {CoLoR }}$ $\mathrm{N}$ ] and the [A come NP] pattern for five color terms (nero 'black', bianco 'white', rosso 'red', azzurro 'light-blue', verde 'green'), using the itTenTen10 corpus (cf. footnote 11), and then I compared the top results of the (manually revised) lists, in order to see if the two constructions occur with the same nouns. It turned out that the two constructions share quite a lot of nouns, thus producing a considerable number of doublets. As an exemplification, see the 15 top ranked hits for rosso 'red' in Table 2, where the grey cells highlight the nouns that both constructions occur with. 
Table 2: Comparing [rosso N] and [rosso come NP]: top ranked results from the itTenTen10 corpus

\begin{tabular}{ll}
\hline [rosso N] 'N-red' & Ns \\
\hline rosso fuoco & (fire) \\
\hline rosso rubino & (ruby) \\
\hline rosso sangue & (blood) \\
\hline rosso porpora & (purple) \\
\hline rosso ciliegia & (cherry) \\
\hline rosso mattone & (brick) \\
\hline rosso corallo & (coral) \\
\hline rosso tramonto & (sunset) \\
\hline rosso fiamma & (flame) \\
\hline rosso fragola & (strawberry) \\
\hline rosso pomodoro & (tomato) \\
\hline rosso ruggine & (rust) \\
\hline rosso vino & (wine) \\
\hline rosso passione & (passion) \\
\hline rosso papavero & (poppy) \\
\hline
\end{tabular}

\begin{tabular}{ll}
\hline [rosso come NP] 'red as NP' & Ns \\
\hline rosso come il sangue & (blood) \\
\hline rosso come il fuoco & (fire) \\
\hline rosso come un peperone & (pepper) \\
\hline rosso come un pomodoro & (tomato) \\
\hline rosso come un gambero & (shrimp) \\
\hline rosso come la passione & (passion) \\
\hline rosso come un papavero & (poppy) \\
\hline rosso come un tacchino & (turkey) \\
\hline rosso come il cuore & (heart) \\
\hline rosso come una ciliegia & (cherry) \\
\hline rosso come un peperoncino & (hot pepper) \\
\hline rosso come la terra & (earth) \\
\hline rosso come la brace & (embers) \\
\hline rosso come il tramonto & (sunset) \\
\hline rosso come il corallo & (coral) \\
\hline
\end{tabular}

A similar picture emerged for other colors. For instance: nero 'black' frequently occurs with pece 'pitch', notte 'night', carbone 'coal', inchiostro 'ink' and petrolio 'oil' in both constructions (vs. e.g. morte 'death', which selects only the simile construction: nero come la morte lit. black like the death 'intense black'); bianco 'white' frequently occurs with latte 'milk', avorio 'ivory', marmo 'marble', neve 'snow', carta 'paper' and cadavere 'corpse' in both constructions (vs. cencio 'rag' and crema 'cream', which occur only in one construction: bianco come un cencio lit. white as a rag 'very pale', bianco crema lit. white cream 'cream-like white'). Therefore, these two constructions share quite a lot of environment and actually seem to compete with each other.

At this point, one may inquire whether they are really equivalent. Take for instance the pairs in (36)-(39), where the (a) examples are taken from the itTenTen10 corpus and the (b) examples contain the corresponding (either MWE or compound) expression. 
(36a) Una villa bianco neve si stagliava su un pendio scosceso

'A snow-white villa stood out on a steep slope'

(36b) Una villa bianca come la neve si stagliava su un pendio scosceso

(37a) Per arrivarci bisogna guadare a piedi un fiume [...] rosso come la ruggine 'To get there you have to cross on foot a rust-like red river'

(37b) Per arrivarci bisogna guadare a piedi un fiume [...] rosso ruggine

(38a) Le occhiaie nero pece mi ricordano della nottata appena trascorsa 'The pitch-black bags under my eyes remind me of the night that has just passed'

(38b) Le occhiaie nere come la pece mi ricordano della nottata appena trascorsa

(39a) I suoi occhi, azzurri come il ghiaccio, mandavano lampi gelidi 'His eyes, blue as the ice, were sending icy flashes'

(39b) I suoi occhi, azzurro ghiaccio, mandavano lampi gelidi

In these pairs, the two expressions seem quite interchangeable. However, a closer analysis of a number of examples showed that interchangeability is possible in specific contexts that meet certain semantic properties, to which I now turn.

I mentioned above that compounds of the $\left[\mathrm{A}_{\mathrm{COLOR}} \mathrm{N}\right]$ type denote, quite neutrally, a kind of color that is typically exemplified by $\mathrm{N}$, whereas the simile construction with color terms, besides denoting a type of color, shares the intensification meaning with the general [A come NP] construction. This intensifying effect is especially prominent when $\mathrm{N}$ refers to an object that is associated with an intense shade, or with the focal shade of the color in question (40a). The intensification effect diminishes when $\mathrm{N}$ identifies a referent that is not associated with such an intense or "prototypical" shade (40b). At the same time, when the compound features an $\mathrm{N}$ that identifies a referent that is associated with such an intense or "prototypical" shade of the color at hand (41a), some slight intensification emerges, otherwise absent in this construction (41b). ${ }^{12}$

(40a) rosso come il sangue (lit. red as the blood) 'blood-red'

$\Rightarrow$ true/intense red

12 Incidentally, the association with an entity $(\mathrm{N})$ that is regarded as a prototypical example of the property conveyed by A might actually be at the basis of the intensification meaning conveyed by the more general [A come NP] construction. 
(40b) rosso come la ruggine (lit. red as the rust) 'rust-like red' $\neq$ true/intense red

(41a) bianco neve (lit. white snow)

'snow-like white / snow-white'

$\Rightarrow$ true/pure white

(41b) bianco avorio (lit. white ivory) 'creamy-white’ $\neq$ true/pure white

The two patterns are more likely to be interchangeable when they tend to "converge", i.e. when the intensification value is low in the $\left[\mathrm{A}_{\mathrm{COLOR}}\right.$ come $\left.\mathrm{NP}\right]$ pattern (cf. (37), (39)) and when some intensification emerges in the $\left[\mathrm{A}_{\text {COLOR }} \mathrm{N}\right]$ pattern (cf. (36), (38)), depending on the kind of $\mathrm{N}$ used. This said, it must be added that even in these specific situations, the two constructions are not totally equal semantically, because the simile construction always has a higher degree of expressiveness, probably inherited by the more general simile construction of which it is an instance. Compounds, on the other hand, are more objective and neutral. In those contexts where they are interchangeable, the two expressions may thus be seen as propositional synonyms (Cruse 2004), i.e. as denotationally equivalent but different in expressive meaning.

Besides semantics, there are a number of formal properties, partially derived from their phrasal vs. morphological status, that differentiate the two constructions. First of all, in the $\left[\mathrm{A}_{\text {COLOR }}\right.$ come NP] pattern the color adjective is variable (see e.g. (39a), where azzurri agrees in number and gender with occhi: plural, masculine), whereas in the compound pattern it is primarily invariable: ${ }^{13}$

\begin{tabular}{|c|c|c|c|c|}
\hline$(42 a)$ & $\begin{array}{l}\text { una } \\
\mathrm{a}\end{array}$ & $\begin{array}{l}\text { maglia } \\
\text { sweater.sG }\end{array}$ & $\begin{array}{l}\text { verde } \\
\text { green.SG }\end{array}$ & $\begin{array}{l}\text { prato } \\
\text { lawn }\end{array}$ \\
\hline & 'a lav & ke green swe & er’ & \\
\hline (42b) & $\begin{array}{l}\text { due } \\
\text { two }\end{array}$ & $\begin{array}{l}\text { maglie } \\
\text { sweater.PL }\end{array}$ & $\begin{array}{l}\text { verde } \\
\text { green.SG }\end{array}$ & $\begin{array}{l}\text { prato } \\
\text { lawn }\end{array}$ \\
\hline & 'two ' & -like green s & eaters’ & \\
\hline (42c) & $\begin{array}{l}{ }^{* \star} d u e \\
\text { two }\end{array}$ & $\begin{array}{l}\text { maglie } \\
\text { sweater.PL }\end{array}$ & $\begin{array}{l}\text { verdi } \\
\text { green.PL }\end{array}$ & \\
\hline
\end{tabular}

Second, in the $\left[\mathrm{A}_{\text {COLOR }}\right.$ come NP] pattern, the color adjective can only be an adjective, whereas the compound may also be used as a noun:

13 Although D’Achille/Grossmann (2013) observed some variation in corpora. 
(43a) Il rosso fuoco non ti si addice

'Fire-like red doesn't befit you'

(43b) `Il rosso come il fuoco non ti si addice

'Red as fire doesn't befit you'

Third, although the two constructions share a lot of nouns, not all nouns are equally likely to occur in both constructions. For instance, the combination of azzurro 'light blue' and polvere 'dust' seems to occur within the compound pattern only (44a), whereas the combination of nero 'black' and buio 'dark' seems to work only within the simile construction (44b).

(44a) azzurro polvere
light_blue dust
'dust-like light blue'
$\begin{aligned} & \text { 'azzurro come la polvere } \\ & \text { light_blue as }\end{aligned}$ the dust
(44b) nero come il buio
black as
'intense black'
'nero the dark
black dark buio

In some cases, the attempt to apply a given A-N combination occurring in one construction to the other construction results in an unacceptable string. This typically happens when $\mathrm{N}$ is an abstract noun (45a-a'), when a metonymy is at work (cf. (45b-b'), where the entity referred to is not a cardinal, but the cardinal's cassock), and when the association with $\mathrm{N}$ has a purely intensifying effect, like in $\left(45 c-c^{\prime}\right)$, where there is no obvious relationship between rags and whiteness.

(45a) giallo tradimento

yellow betrayal

'typical yellow (color associated with betrayal)'

(45a') *giallo come il/un tradimento

yellow as a/the betrayal

(45b) rosso cardinale

red cardinal

'cardinal red'

(45b') *rosso come un cardinale

red as a cardinal 


(45c) bianco come un cencio
white as a rag
'very pale'
(45c') $\begin{aligned} & \text { *bianco cencio } \\ & \text { white rag }\end{aligned}$

In conclusion, what emerges from this overall picture is that the two constructions are not really equivalent in terms of both meaning and form. In some specific instances the two versions - compound and multiword - are pretty close and possibly competing with one another (although the multiword version is generally more expressive), but even in these cases they have partially different structural properties. Besides, they do not share the whole array of possible A-N pairs. In other words, the two constructions seem to do their best not to overlap too much, and to differentiate from each other.

\subsection{Coordination in the lexicon: irreversible binomials vs. compounds}

The last case-study I am going to briefly discuss concerns morphological and multiword coordinating constructions. As exemplified below, Italian displays both coordinate compounds (46) and so-called "irreversible binomials" (cf., among many others, Malkiel 1959; Lambrecht 1984; Masini 2006 for Italian) (47):

(46a) sordo-muto

deaf-mute

'deaf-mute'

(46b) studente-lavoratore

student-worker

'student-worker'

(46c) agro-dolce

sour-sweet

'sweet and sour, bittersweet'

(46d) ceco-slovacco

Czech-Slovak

'Czechoslovak'

(47a) sano $e$ salvo

healthy and safe

'safe and sound' 


$\begin{array}{lll}\text { (47b) vivo } e & \text { vegeto } \\ \text { alive and thriving } \\ \text { 'alive and well' }\end{array}$

Along the lines of the pattern for coordinate compounds, we might theoretically form compounds like those in (48): however, these expressions are not actually created by speakers because the corresponding binomials already exist (47a-b).
(48a) ${ }^{\circ}$ sanosalvo healthy-safe
(48b) ${ }^{\circ}$ vivo-vegeto alive-thriving

The reverse situation may also occur: for instance, the existence of an established coordinate compound like sordomuto (46a) blocks the formation, or lexicalization, of the corresponding irreversible binomial (49), which would be technically well-formed.

$\begin{array}{lll}{ }^{\circ} \text { sordo } & e & \text { muto } \\ \text { deaf } & \text { and }\end{array}$

To which extent are these two patterns - coordinate compounds and irreversible binomials - actually equivalent? Let us take a step back.

Arcodia/Grandi/Wälchli (2010: 178) propose a macro-distinction between: i) "hyperonymic coordinate compounds" (what Wälchli 2005 calls "co-compounds"), which express superordinate-level concepts, i.e. their referent is in a superordinate relationship to the meaning of the parts (cf. (50a)); ii) "hyponymic coordinate compounds", which express subordinate-level concepts, i.e. their referent is in a subordinate relationship to the meaning of the parts (cf. (50b)). They also claim that, whereas the latter are common in Standard Average European (SAE) languages, including of course Italian (cf. also Grandi 2011), the former are more typically found in East and South East Asia.

(50a) dāo-qiāng

(Mandarin) sword-spear 'weapons' 
(50b) lanza-espada

(Spanish) spear+sword

'a spear with a blade, i.e. a spear which is a sword at the same time'

In addition, Wälchli (2005) shows that co-compounds in the world's languages may be classified into different semantic types according to the relationship between the whole and the constituents. Most of the (non-compositional) meanings identified by Wälchli (2005: 138) for co-compounds crosslinguistically are not found in Italian coordinate compounds (which are typically of the "hyponymic" type), like for instance the generalizing meaning (51), the collective meaning (52), or the approximate meaning (53).

(51) Generalizing (= the output universally quantifies over the input)

t'ese-toso

(Mordvin)

here-there

'everywhere'

(52) Collective (= the output is a hypernym of the input items)

sět-śu

(Chuvash)

milk-butter

'dairy products'

(53) Approximate (= the output is an approximation w.r.t. the input)

ob peb

(White Hmong)

two three

'some'

However, Masini (2006, 2012) shows that most of these functions are actually found in Italian, but they are conveyed by irreversible binomials (cf. (54a), (55a), (56a)). Most likely the same holds for other SAE languages: see for instance the English examples in (54b), (55b) and (56b).

(54) Generalizing

(54a) giorno $e$ notte

(Italian)

day and night

'day and night, always'

(54b) high and low (meaning 'everywhere')

(English) 
(55) Collective

(55a) coltello e e forchetta (Italian) knife and fork 'cutlery'

(55b) bra and panties (meaning 'lingerie’) (English)

(56) Approximate

(56a) poco o niente (Italian) little or nothing 'very little, almost nothing'

(56b) two or three (meaning 'some')

Therefore, despite their structural resemblance, the actual competition between the two coordinating strategies under examination is quite limited, since the two patterns are similar but not equivalent: although they might compete in some specific cases (cf. the semantic similarity between sordomuto 'deaf-mute', being the sum of deaf and mute, and vivo e vegeto 'alive and well', being the sum of alive and thriving), overall the two patterns are specialized for different functions, compensating, so to speak, for one another.

\section{Towards a unified treatment of complex lexical items}

In this paper I dealt with complex lexical items in Italian, namely proper compounds and MWEs. Specifically, I focused on so-called phrasal lexemes, which are closer to compounds in distribution and function than other (e.g. sentence-level) MWEs. Whereas compounds mostly feed nouns and adjectives in Italian, phrasal lexemes - beside creating expressions belonging to nouns/adjectives - may also feed other major word classes, most notably verbs and adverbs, thus apparently compensating the limits of compounding in these specific areas. What should be stressed, once again, is that phrasal lexemes are not just the product of diachronic lexicalization: some instances certainly are, but some others are the result of synchronic lexical creation that relies on stored naming patterns (i.e., constructions).

The demarcation between compounds and phrasal lexemes turned out to be a non-trivial issue. I proposed four tentative criteria for the Italian language, i.e. presence/absence of: internal agreement, explicit relational markers, minor lexical categories, bounded elements. However, this set of criteria has no pretense of 
crosslinguistic validity: in fact, each language will display a specific set of properties that help distinguishing between these two kinds of constructions (when this is actually possible). Ultimately, these criteria trace back to the traditional distinction between morphology and syntax, which is however not clear-cut within a constructionist view of the grammar.

I also contributed some data and observations on the competition that quite expectedly - emerges between compounds and phrasal lexemes, given their shared function. I showed that this competition may lead to bidirectional blocking: compounds may block the establishment of a phrasal lexeme in the lexicon, and an established phrasal lexeme may block the creation of a new compound. From the data examined so far, it seems that these two competing patterns tend to differentiate, by specializing for different functions (cf. especially Sections 4.2 and 4.3). This goes into the direction advocated for by Aronoff (2016, to appear) in recent work, where competition leads to either extinction of one of the competitors, or to differentiation in terms of form, meaning or distribution, as a result of a "struggle for existence" between linguistic expressions.

In conclusion, the discussion of demarcation and competition issues carried out in this chapter suggests a view of the mental lexicon where both compounds and phrasal lexemes are stored, on a par with each other: they share the same function and distribution, they may compensate for each other at the most abstract level, and they definitely compete with each other for the expression of lexico-conceptual meanings.

\section{References}

Ackerman, Farrell/Webelhuth, Gert (1997): The composition of (dis)continuous predicates: Lexical or syntactic? In: Acta Linguistic Hungarica 44, 3/4. 317-340.

Arcodia, Giorgio Francesco/Grandi, Nicola/Wälchli, Bernhard (2010): Coordination in compounding. In: Scalise, Sergio/Vogel, Irene (eds.). 177-197.

Aronoff, Mark (2016): Competition and the lexicon. In: Elia, Annibale/lacobini, Claudio/ Voghera, Miriam (eds.): Livelli di analisi e fenomeni di interfaccia. Roma: Bulzoni. 39-52.

Aronoff, Mark (to appear): Competitors and alternants in linguistic morphology. In: Rainer, Franz/Gardani, Francesco/Dressler, Wolfgang U./Luschützky, Hans Christian (eds.).

Baldwin, Timothy/Kim, Su Nam (2010): Multiword expressions. In: Indurkhya, Nitin/Damerau, Fred J. (eds.): Handbook of Natural Language Processing. Boca Raton: CRC Press. 267-292.

Benveniste, Émile (1966): Différentes formes de la composition nominale en français. In: Bulletin de la Société de Linguistique de Paris 61, 1. 82-95.

Bernal, Elisenda (2012): Catalan compounds. In: Probus 24, 1. 5-27. 
Bisetto, Antonietta (2004): Composizione con elementi italiani. In: Grossmann, Maria/Rainer, Franz (eds.). 33-51.

Bisetto, Antonietta/Scalise, Sergio (1999): Compounding. Morphology and/or syntax? In: Mereu, Lunella (ed.): Boundaries of Morphology and Syntax. Amsterdam/Philadelphia: Benjamins. 31-48.

Booij, Geert (2002a): Constructional idioms, morphology and the Dutch lexicon. In: Journal of Germanic Linguistics 14, 4. 301-329.

Booij, Geert (2002b): Separable complex verbs in Dutch: A case of periphrastic word formation. In: Dehé, Nicole et al. (eds.): Verb-Particle Explorations. Berlin/New York: De Gruyter. 21-42.

Booij, Geert (2009a): Phrasal names: A constructionist analysis. In: Word Structure 2, 2. 219-240.

Booij, Geert (2009b): Lexical integrity as a formal universal: A constructionist view. In: Scalise, Sergio/Magni, Elisabetta/Bisetto, Antonietta (eds.). 83-100.

Booij, Geert (2010): Construction Morphology. Oxford: Oxford University Press.

Butt, Miriam (1995): The structure of complex predicates in Urdu. Stanford: CSLI.

Cacciari, Cristina/Tabossi, Patrizia (eds.) (1993): Idioms: Processing, structure, and interpretation. Hillsdale: Psychology Press.

Cowie, Anthony (ed.) (1998): Phraseology: Theory, analysis, and applications. Oxford: Oxford University Press.

Cruse, Alan (2004): Meaning in language. Oxford: Oxford University Press.

D’Achille, Paolo/Grossmann, Maria (2010): I composti aggettivo + aggettivo in italiano. In: Iliescu, Maria/Siller-Runggaldier, Heidi M./Danler, Paul (eds.): Actes du XXVe Congrès International de Linguistique et de Philologie Romanes (3-8 sept. 2007, Innsbruck), VII. Berlin/New York: De Gruyter. 405-414.

D’Achille, Paolo/Grossmann, Maria (2013): I composti <colorati> in italiano tra passato e presente. In: Casanova Herrero, Emili/Calvo Rigual, Cesáreo (eds.): Actas del XXVI Congreso Internacional de Lingüística i Filología Románicas (Valencia, 6-11 de septiembre 2010). Berlin/New York: De Gruyter. 523-537.

Dehé, Nicole et al. (eds.) (2002): Verb-particle explorations. Berlin: De Gruyter.

Delfitto, Denis/Melloni, Chiara (2009): Compounds don't come easy. In: Lingue e Linguaggio VIII(1). 75-104.

Everaert, Martin et al. (eds.) (1995): Idioms: Structural and psychological perspectives. Hillsdale.

Fillmore, Charles/Kay, Paul/O'Connor, Mary Catherine (1988): Regularity and idiomaticity in grammatical constructions: The case of let alone. Language 64, 3. 501-538.

Giegerich, Heinz J. (2005): Associative adjectives in English and the lexicon-syntax interface. In: Journal of Linguistics 41, 3. 571-591.

Giegerich, Heinz J. (2009): The English compound stress myth. In: Word Structure 2, 1. 1-17.

Grandi, Nicola (2011): La coordinazione tra morfologia e sintassi. Tendenze tipologiche ed areali. In: Massariello Merzagora, Giovanna/Dal Maso, Serena (eds.): I luoghi della traduzione/Le interfacce. Roma: Bulzoni. 881-895.

Grossmann, Maria/Rainer, Franz (eds.) (2004): La formazione delle parole in italiano. Tübingen: Niemeyer.

Guevara, Emiliano/Scalise, Sergio (2009): Searching for universals in compounding. In: Scalise, Sergio/Magni, Elisabetta/Bisetto, Antonietta (eds.). 101-128. 
Haspelmath, Martin (2011): The indeterminacy of word segmentation and the nature of morphology and syntax. In: Folia Linguistica 45, 1. 31-80.

Hoffmann, Thomas/Trousdale, Graeme (eds.) (2013): The Oxford Handbook of Construction Grammar. Oxford: Oxford Handbooks.

Hüning, Matthias/Schlücker, Barbara (2015): Multi-word expressions. In: Müller, Peter O. et al. (eds.). 450-467.

lacobini, Claudio (2015): Particle-verbs in Romance. In: Müller, Peter O. et al. (eds.). 627-659.

lacobini, Claudio/Masini, Francesca (2007): The emergence of verb-particle constructions in Italian. In: Morphology 16, 2: 155-188.

Jackendoff, Ray (1990): Semantic structures. Cambridge, MA: MIT Press.

Jackendoff, Ray (1995): The boundaries of the lexicon. In: Everaert, Martin et al. (eds.). 133-165. Jackendoff, Ray (1997): The architecture of the language faculty. Cambridge, MA: MIT Press.

Jackendoff, Ray (2010): Meaning and the lexicon: the Parallel Architecture 1975-2010. Oxford: Oxford University Press.

Jezek, Elisabetta (2004): Types et degrés de verbes supports en italien. In: Linguisticae investigationes 27, 2: 185-201.

Kay, Paul (2013): The limits of (Construction) Grammar. In: Hoffmann, Thomas/Trousdale, Graeme (eds.). 32-48.

Lambrecht, Knud (1984): Formulaicity, frame semantics, and pragmatics in German binomial expressions. In: Language 60, 4. 753-796.

Malkiel, Yakov (1959): Studies in irreversible binomials. In: Lingua 8. 113-160.

Masini, Francesca (2005): Multi-word expressions between syntax and the lexicon: the case of Italian verb-particle constructions. In: SKY Journal of Linguistics 18. 145-173.

Masini, Francesca (2006): Binomial constructions: Inheritance, specification and subregularities. In: Lingue e Linguaggio 5, 2. 207-232.

Masini, Francesca (2009): Phrasal lexemes, compounds and phrases: A constructionist perspective. In: Word Structure 2, 2. 254-271.

Masini, Francesca (2012): Parole sintagmatiche in italiano. Roma: Caissa Italia.

Masini, Francesca (2016): Morphological words and multiword expressions: Competition or cooperation? Paper given at the $17^{\text {th }}$ International Morphology Meeting (IMM17), Vienna, 18-21 February 2016.

Masini, Francesca (to appear): Competition between morphological words and multiword expressions. In: Rainer, Franz/Gardani, Francesco/Dressler, Wolfgang U./Luschützky, Hans Christian (eds.).

Masini, Francesca/Benigni, Valentina (2012): Phrasal lexemes and shortening strategies in Russian: The case for constructions. In: Morphology 22, 3. 417-451.

Masini, Francesca/Scalise, Sergio (2012): Italian compounds. In: Probus 24, 1. 61-91.

Masini, Francesca/Thornton, Anna M. (2008): Italian VeV lexical constructions. In: On-line Proceedings of the $6^{\text {th }}$ Mediterranean Morphology Meeting (MMM6). University of Patras. 146-186.

Moon, Rosamund (1998): Fixed expressions and idioms in English: A corpus-based approach. New York: Clarendon Press.

Müller, Peter O. et al. (eds.) (2015): Word-formation. An international handbook of the languages of Europe. Vol. 1. (= Handbooks of Linguistics and Communication Science (HSK) 40.1). Berlin/Boston: De Gruyter.

Radimský, Jan (2015): Noun+Noun compounds in Italian: A corpus-based study. České Budějovice: University of South Bohemia in České Budějovice. 
Rainer, Franz (1988): Towards a theory of blocking: The case of Italian and German quality nouns. In: Booij, Geert/van Marle, Jaap (eds.): Yearbook of Morphology 1988. Dordrecht: Springer. 155-185.

Rainer, Franz (2016): Blocking. In: Aronoff, Mark (ed.): The Oxford Research Encyclopedia of Linguistics. Internet: DOI: 10.1093/acrefore/9780199384655.013.33.

Rainer, Franz/Varela, Soledad (1992): Compounding in Spanish. In: Rivista di Linguistica 4, 1. 117-142.

Rainer, Franz/Gardani, Francesco/Dressler, Wolfgang U./Luschützky, Hans Christian (eds.) (to appear): Competition in inflection and word formation. Cham: Springer.

Ricca, Davide (2010): Corpus data and theoretical implications with special reference to Italian V-N compounds. In: Scalise, Sergio/Vogel, Irene (eds.). 237-254.

Rio-Torto, Graça/Ribeiro, Sílvia (2009): Compounds in Portuguese. In: Lingue e Linguaggio VIII(2). 271-291.

Rio-Torto, Graça/Ribeiro, Sílvia (2012): Portuguese compounds. In: Probus 24, 1. 119-145.

Scalise, Sergio (1992): Compounding in Italian. In: Italian Journal of Linguistics/Rivista di Linguistica 4, 1. 175-199

Scalise, Sergio/Bisetto, Antonietta (2009): The classification of compounds. In: Lieber, Rochelle/Štekauer, Pavol (eds.): The Oxford handbook of compounding. Oxford: Oxford University Press. 34-53.

Scalise, Sergio/Magni, Elisabetta/Bisetto, Antonietta (eds.) (2009): Universals of language today. Berlin: Springer.

Scalise, Sergio/Vogel, Irene (eds.) (2010): Cross-disciplinary issues in compounding. Amsterdam: Benjamins.

Schlücker, Barbara/Hüning, Matthias (2009): Compounds and phrases. A functional comparison between German $\mathrm{A}+\mathrm{N}$ compounds and corresponding phrases. In: Italian Journal of Linguistics 21, 1. 209-234.

Voghera, Miriam (2004): Polirematiche. In: Grossmann, Maria/Rainer, Franz (eds.). 56-69.

Wälchli, Bernhard (2005): Co-compounds and natural coordination. Oxford: Oxford University Press. 
